Kinestetik : Jurnal Ilmiah Pendidikan Jasmani 5 (1) (2021)

Kinestetik : Jurnal Ilmiah Pendidikan Jasmani

https://ejournal.unib.ac.id/index.php/kinestetik/index

DOI 10.33369/jk.v5i1.14617

\title{
EVALUATION OF PHYSICAL EDUCATION IN SLB-C OF SOUTH KALIMANTAN PROVINCE
}

\section{Imam Yuwono ${ }^{1 *}$}

${ }^{1}$ Faculty of Teacher Training Education, Universitas Lambung Mangkurat, Indonesia

\begin{tabular}{l} 
Article Info \\
\hline Article History : \\
Received : February 2021 \\
Revised : February 2021 \\
Accepted : March 2021 \\
Available online : March \\
2021 \\
\hline
\end{tabular}

Keywords:

Learning Evaluation, Physical Education

\begin{abstract}
This study aims to determine the level of success of learning in Physical Education, Sports and Health (Physical Education) class IX 2018/2019 academic year at SLB-C of South Kalimantan Province and to produce recommendations for decision makers to follow up on the ongoing learning program. The evaluation model used in this research is the CIPP evaluation model using descriptive statistical analysis techniques with percentages. This technique is used to analyze data obtained from the results of distributing questionnaires, and uses a model developed by (Daniel Stufflebeam, 2014), namely (1) context, (2) input, (3) process, and (4) product or what is called CIPP. Data were collected from observations, questionnaires, and documentation studies. The results of this study indicate that the overall variable of SLB-C of South Kalimantan Province gets a percentage of $70.5 \%$ with good criteria. Based on the results of these data, it can be decided that overall educational learning in the State Special School Guidance for South Kalimantan Province is in good criteria. Recommendations based on the results of this study are to continue the learning program, but accompanied by revisions to several variables.
\end{abstract}




\section{INTRODUCTION}

Learning health and recreational physical education is a process of interaction between students and the environment through physical activity (Widiyatmoko, F. A., \& Hudah, 2017) the physical education learning process in schools is directed to empower all the potential that students have, namely affective, cognitive, and psychomotor (Webiantoro, E., Wiradihardja, S., \& Nuraini, 2020) In addition to these objectives, quality must be realized in learning, including creativity, independence, cooperation, solidarity, leadership, empathy, tolerance and life skills of students in order to shape character and improve civilization and national dignity. It can be concluded that physical education learning in schools is not only a subject that develops knowledge competencies, thinking skills, psychomotor skills but also in the form of attitudes, characters.

The development must be adjusted to the characteristics, material, needs, and environment. There are several factors that can make students become qualified individuals. Not only external factors such as learning facilities, teacher competence, and social conditions but also internal factors such as motivation and intellectual abilities. A professional teacher has a good impact on the learning process. (Werdayanti, 2008)

The teacher's role in managing the classroom well is needed to achieve this. Knowledge of learning orientation must be adjusted to the child's development, content and material affairs in delivery must be adjusted so that it is interesting and enjoyable.(Saputra, 2015) In addition, the basic concepts of physical education and effective learning models must be understood by teachers.

However, in its implementation, it is based on field notes made by researchers that Physical Education teachers, especially in the SLB-C area of South Kalimantan Province, still do not fully understand and have difficulties in implementing the implementation of Physical Education learning. Physical education teachers generally still equate perceptions between Physical Education and Sports, even though the concepts of physical education and sports are very different. Besides that, the subject of Physical Education seems to be only a complement so that it doesn't get much attention. (Munthe, 2015)

With this problem, researchers will evaluate the seventh grade learning $2018 / 2019$ academic year in the subject of Physical Education in all SLB-C of 
South Kalimantan Province using the CIPP model approach (context, input, process, product).

\section{METHODS}

The research methods used in evaluation can be grouped into quantitative methods, qualitative methods, and mixed methods (Wirawan, 2012). In this evaluation study using a mixed method of qualitative and quantitative. There are several reasons why you should use mixed research methods, including theoretical considerations and practical considerations (Wirawan, 2012). Theoretical considerations are related to the data needed to achieve the evaluation objectives while practical considerations relate to time, effort and cost. In addition, using mixed methods will produce more relevant results. Because the qualitative method allows the evaluator to examine the object of evaluation in depth and in detail, but only in terms of the number of respondents. On the other hand, the advantage of using quantitative methods is that it can capture large amounts of data and can be presented in numerical form so that it is easy to analyze. While the research design refers to the research model using the CIPP research model (context, input, process, product). (Daniel Stufflebeam, 2014)

\section{Participants}

The sample in this study were 4 physical education teachers and school principals in SLB-C South Kalimantan.

\section{Sampling Procedures}

The sample is part of the number and characteristics possessed by these characteristics. (Arikunto, 2010). The sampling process with purposive sampling is a sampling technique with certain considerations, so in this study all physical education teachers became a sample of 4 people to be sampled.

\section{Materials and Apparatus}

The data collection technique used a questionnaire, the questionnaire was carried out on the consideration of the respondent who had time to answer the questions asked and had the freedom to give answers. In filling in order to make it easier for respondents to answer, a closed questionnaire is used and respondents are asked to choose one of several prepared answers.

\section{Procedures}

The procedure in this research, the researcher gives a question that has been made and validated to the physical education teacher, besides that, also by using documentation, namely the availability of learning facilities in schools. This is done in order to explore information that cannot be obtained through documents or observations of the object of research. The form of questions carried out in this study are questions that are carried out in the interests of collecting data to answer research.

\section{Design or Data Analysis}

The data analysis techniques used in the evaluation of this program are quantitative and qualitative data analysis techniques. These differences depend on 
the amount and nature of the data collected. If the data obtained is descriptive in nature that cannot be converted into numbers, then the analysis uses qualitative analysis. This qualitative data analysis is inductive in nature, meaning that an analysis of the data obtained will later be developed into a hypothesis.

The components in data analysis, in analyzing qualitative data, must be carried out in several stages, namely data reduction, data display and data conclusion.

\section{RESULT}

The results of this study are the context variable gets a percentage of $65 \%$ which means good, the input variable gets a percentage of $72 \%$ which means good, the process variable gets a percentage of $70 \%$ which means good and the product variable gets a percentage of $75 \%$ which means also good. then can be seen in the following diagram:

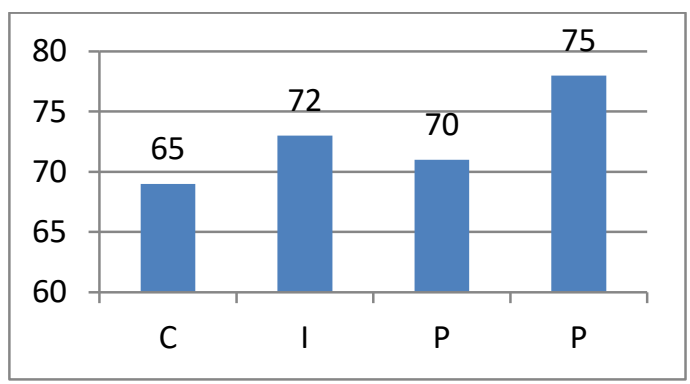

Fig 1. Results of Overall Analysis of CIPP Variable Physical Education Learning Program

\section{DISCUSSION}

Context Variables, evaluatively the results of the context variable for the whole SLB-C of South Kalimantan Province obtained a percentage of $65 \%$ with criteria.

This shows that it has understood the needs in teaching such as learning tools. In addition, teachers also understand the objectives of learning in physical education, sports, and health (physical education).

Input Variables. Evaluatively, the results of the overall input variable of the State Special School Guidance Program of South Kalimantan Province obtained a percentage of $72 \%$ with good criteria,

Teacher input and student input play a very important role in the achievement of learning objectives. With teachers who are in accordance with the competence of their fields, the learning process will be carried out well or at least if not all have been achieved, errors can be minimized and corrected (Hsb, 2018).

For students who have a background with a good intellectual level, it will make it easier for students to learn motion, because in physical education aspects of motor skills are very necessary.

Process Variables, In a good learning the role of the process is important. In a process there are 3 stages that must always exist, namely planning, implementing and evaluating in teaching. Evaluatively, the results of the process variables of the whole SLB-C of the Guidance School of South Kalimantan Province obtained a percentage of $70 \%$ with good criteria. 
At the implementation stage, even so student involvement, the development of attitude values is important because this will shape the character of these students. Meanwhile, the evaluation stage plays a role in measuring the suitability of the initial objectives with the results achieved in a lesson. This can also be used to make innovations or developments related to strategies, models, styles, or even modification of tools for better learning.

Product Variables, Evaluatively, the results of the product variables for the State Special School Guidance Program of South Kalimantan Province obtained a percentage of $75 \%$ with good criteria. Evaluation in education must be carried out for achievement in a program. (Hanafy, 2014), the role of a parent in student success is very important, (Umar, 2015) besides that, the quality of teachers is also a major factor in the success of student learning outcomes (Wulandari, 2012).

\section{CONCLUSION}

In the context of the evaluation of physical education learning for the even semester of the 2018/2019 academic year at the State Special School Guidance for South Kalimantan Province which is related to the needs and learning objectives, the percentage of achievement is $65 \%$ with good criteria. In the input related to human resources, facilities and infrastructure, the percentage of achievement was $72 \%$ with good criteria. In the process related to planning, implementing, and evaluating learning, the percentage of achievement was $70 \%$ with good criteria. In products related to student learning outcomes (affective, psychomotor, cognitive, psychomotor), the percentage of achievement is $75 \%$ with good criteria.

It can be concluded that the evaluation of the class IX physical education learning program for the even semester of the 2015/2016 academic year at SLB-C of South Kalimantan Province as a whole has a good. In physical education, an evaluation is needed to determine the achievement of educational outcomes. (Betwan, 2019) (Widiatmoko, F. A., \& Hudah, 2017) Moreover, there is learning for children with special needs (SLB) (Yuniartik, H., Hidayah, T., \& Nasuka, 2017).

\section{ACKNOWLEDGEMENT}

Thanks to the physical education teachers of the SLB-C South Kalimantan and the Dean of the FKIP ULM who have supported the writing of this article.

\section{REFERENCES}

Arikunto, S. (2010). Metode peneltian. Rineka Cipta.

Betwan, B. (2019). Pentingnya Evaluasi Afektif Pada Pembelajaran Pai Di Sekolah. Al-Fikri. Jurnal Studi Dan Penelitian Pendidikan Islam, 2(1), 4560.

Daniel Stufflebeam. (2014). Evaluation, Theory, Models And Application. Jossey Bass.

Hanafy, M. S. (2014). Konsep Belajar Dan Pembelajaran. Lentera Pendidikan: Jurnal Ilmu Tarbiyah Dan Keguruan. Https://Doi.Org/10.24252/Lp.2014v17n 
$1 \mathrm{a} 5$

Hsb, A. A. (2018). Kontribusi Lingkungan

Belajar Dan Proses Pembelajaran Terhadap Prestasi Belajar Siswa Di Sekolah. Jurnal Tarbiyah. Https://Doi.Org/10.30829/Tar.V25i2.36 5

Munthe, A. P. (2015). Pentingnya Evaluasi Program Di Institusi Pendidikan: Sebuah Pengantar, Pengertian, Tujuan Dan Manfaat. Scholaria: Jurnal Pendidikan Dan Kebudayaan, 5(2), 114.

Saputra. (2015). Modifikasi Media Pembelajaran Pendidikan Jasmani Sekolah Dasar. Jurnal Ilmu Keolahragaan, 14(2), 35-41.

Umar, M. (2015). Peranan Orang Tua Dalam Peningkatan Prestasi Belajar Anak. Jurnal Edukasi: Jurnal Bimbingan Konseling.

Https://Doi.Org/10.22373/Je.V1i1.315

Webiantoro, E., Wiradihardja, S., \& Nuraini, S. (2020). Permainan., Model Pembelajaran Lokomotor Usia 6-7 Tahun Berbasis. Jurnal Ilmu Keolahragaan, 19(1), 20-27.

Werdayanti, A. (2008). Pengaruh Kompetensi Guru Dalam Proses Belajar Mengajar Di Kelas Dan Fasilitas Guru Terhadap Motivasi Belajar Siswa. Dinamika Pendidikan, 3(1).

Widiatmoko, F. A., \& Hudah, M. (2017). Evaluasi Implementasi Pendidikan Nilai Dalam Pembelajaran Penjas. Jurnal Ilmiah Penjas (Penelitian, Pendidikan Dan Pengajaran), 3(2).

Widiyatmoko, F. A., \& Hudah, M. (2017). No Title. Jurnal Ilmiah Penjas (Penelitian, Pendidikan Dan Pengajaran), 3(2).

Wirawan. (2012). Evaluasi Teori, Model, Standar, Aplikasi, Dan Profesi. Rajagrafindo Persada.

Wulandari, D. (2012). Pengaruh Kompetensi Pedagogik Dan Kompetensi Profesional Guru Terhadap Economic Literacy Melalui Prestasi Belajar Siswa Kelas Xii Ips Di Sma Kota Malang. Jurnal Pendidikan Humaniora.

Yuniartik, H., Hidayah, T., \& Nasuka, N. (2017). Evaluasi Pembelajaran Pendidikan Jasmani Olahraga Dan Kesehatan Di Slb C Se-Kota
Yogyakarta. Journal Of Physical Education And Sports, 6(2), 148-156. 